\title{
Effects of Forest Cover Change on Flood Characteristics in the Upper Citarum Watershed
}

\author{
Bambang Dwi Dasanto ${ }^{1 *}$, Bambang Pramudya ${ }^{2}$, Rizaldi Boer $^{3}$, Yuli Suharnoto ${ }^{4}$ \\ 'Graduate School of Bogor Agricultural University, Dramaga Main Road, Campus IPB Dramaga, Bogor, Indonesia 16680 \\ ${ }^{2}$ Department of Mechanical and Biosystem Engineering, Faculty of Agricultural Technology, Bogor Agricultural University, \\ Academic Ring Road, Campus IPB Dramaga, Bogor, Indonesia 16680 \\ ${ }^{3}$ Department of Geophysics and Meteorology, Faculty of Mathematics and Natural Sciences, Bogor Agricultural University, \\ Academic Ring Road, Campus IPB Dramaga, Bogor, Indonesia 16680 \\ ${ }^{4}$ Department of Civil Engineering and Environmental, Faculty of Agricultural Technology, Bogor Agricultural University, \\ Academic Ring Road, Campus IPB Dramaga, Bogor, Indonesia 16680
}

Received July 23, 2014/Accepted October 27, 2014

\begin{abstract}
Information on the effect of forest cover changes on streamflow (river discharge) in large-scale catchment is important to be studied. The rate of forest cover change in the Upper Citarum Watershed as a large-scale catchment is high enough to drive streamflow change, such as increase of discharge level, or flood volume. Within the research area, flood would occur when the volume of streamflow exceeded the canal capacity and inundated areas that were normally dry. Therefore, this research focused on identifying the effects of forest cover change on flood events and its distribution. The research consisted of 2 main stages; firstly, building geometric data of river and performing frequency analysis of historical and scenario discharges using an approach of probability distribution; and, secondly, flood inundation mapping using HEC-RAS model. The results showed that forest reduction have affected water yield in the downstream of Upper Citarum Watershed. In each return period, this reduction have increased river discharge level and affected the spread offlooded areas. In 2-year return period, the extent of flood as an impact offorest reduction was estimated to decrease slowly. However, in the return period of more than 2 years, the spread of flooded areas increased sharply. These proved that forest cover reduction would always increase the discharge value, but it did not always expand the inundated area.
\end{abstract}

Keywords: geometric data, forest cover, water yield, return period

*Correspondenceauthor, email: bambangdwi@ipb.ac.id, tel.: +62-251-8623850,fax.:+62-251-8623850

\section{Introduction}

Citarum River plays a vital role for West Java citizens; including fulfillment of water for domestic, industries, and irrigation purposes (Fares \& Yudianto 2004). Such role, however, is decreasing due to the degrading Citarum Watershed quality which increases its susceptibility to both flood and drought (Apip et al. 2010; Boer et al. 2012). It is for this reason that problems in Citarum Watershed have to be immediately responded with accuracy. One of the efforts to overcome flood related-problems is by providing the public with convincing information on flood risk through flood inundation map (Cook \& Merwade 2009).

The development of flood inundation map can be carried out by using 1D (one-dimensional) and 2D (twodimensional) approach; in which the former approach uses HEC-RAS model, while the later uses FESWMS model. According to Cook (2008), 1D model assumes that all water flows in the longitudinal direction; whereas in the 2D model, water flows in both longitudinal and lateral directions. Furthermore, in 1D model, river bathymetry (bed topography) is represented by a set of cross sections; which does not actually represent the real topography. In 2D model, however, this is represented by a continuous surface model; namely, finite element mesh, and this better represents the real topography (Hunter et al. 2007). However, such model requires relatively more detail topographic data compared to 1D model. Horritt and Bates (2002) point out that, without detail topographic data, the two models (1D and 2D) show relatively similar performances. Since this research was using topographic data with $30 \mathrm{~m}$ horizontal resolution, the 1D approach has been selected to complete the flow dynamic and maps the inundated areas of the Upper Citarum Watershed.

Dingman (1994) states that flood will occur when watershed system experiences uncommon conditions, such as high rainfall or continuous rainfall, causing river discharge (streamflow) rate to exceed canal capacity. Apart from high rainfall, another factor causing the increase of river discharge is the change in land use, e.g. forest into non-forest (Bruijnzeel 1990; Sahin \& Hall 1996; Costa et al. 2003; Du et al.2012).

Over the past 100 years, the relationship between forest changes and water yield (e.g. river discharge, peak discharge, or annual average flood volume) has become an important 
research topic, and this is studied by using direct experiment on catchment scale. Generally, these researches (Hibbert 1967; Bosch \& Hewlett 1982; Andre' assian 2004; Brown et al. 2005) use paired catchment experiments approach. The general conclusion indicate that forest cover reduction (deforestation) will increase water yield, whereas reforestation in opened land will decrease it (Bosch \& Hewlett 1982; Andre'assian 2004; Farley et al. 2005; Lima et al. 2012). The amount of this reduction varies from one experiment to another (Bruijnzeel 2004), and this is caused by a complex interaction among vegetation, climate, and soil (Zhou et al. 2010). Water yield changes is very much affected by landuse change (especially, forest cover change); and, this is determined by time-scale and catchment size (Brown et al. 2005). In short term, deforestation will increase water yield; generally, this hydrologic response appears on a small-scale catchment $\left(<1 \mathrm{~km}^{2}\right)$, while for larger watershed $\left(>100 \mathrm{~km}^{2}\right)$ the impacts can either be the same or the opposite (Wilk 2002; Costa et al. 2003; Brown et al. 2005; Peña-Arancibia et al. 2012; Hendrayanto \& Sudomo 2013). Moore and Wondzell (2007) use the term forest harvesting to depict deforestation process. Research have shown that forest harvesting has increased streamflow and rates of snowmelt and generally, such condition will occur in small headwater catchments $\left(<1 \mathrm{~km}^{2}\right)$. This shows that forest's role and its impact on water yield (including hydrologic cycle) varied and is still debated (Andre' assian 2004; Ellison et al. 2012). Based on the weakness, this researches use a single catchment approach to evaluate the impacts of forest reduction on river discharge at large scale catchment (i.e. Upper Citarum watershed). Wang and Yang (2013) have used single catchment approach (i.e. Chaobai Watershed) to evaluate the effect of land cover (e.g. urban land, cultivated land, and forest) change on flood. They have integrated land use/cover change (LUCC) analysis, hydraulic modeling and statistical method to estimate the effect of LUCC on floods, which is in line with our research approach. Ths reserach aims to identify the effects of forest cover change on river discharge and spread of flood. Return period of river discharge will be estimated using probability distribution method (theoretical frequency distribution), whereas spread of flood inundation is mapped using 1D HEC-RAS hydraulic model.

\section{Methods}

According to USACE (2010), HEC-RAS contains 4 onedimensional river analysis components, i.e. (1) calculate a steady flow of water surface profile, (2) simulate an unsteady flow, (3) sediment transport/mobile bed computations, and (4) water quality analysis. This research only employed one ability, that is, to calculate water surface profiles for steady flow. In this model, calculation of water surface profiles was carried out along the river channel; and this was conducted in order, from one cross section to the next. The depth of water surface was calculated using energy equation and completed with iterative procedures known as standard step method (USACE 2010). In the current version (HEC RAS 4.1.0), the model has been integrated in GIS software. Based on this, the spread of flood inundation can be estimated and mapped. Details of this model can be found in user's manual of HEC-

\section{GeoRAS (USACE 2002).}

River geometry Data were extracted from digital elevation model (DEM) data assisted by digital topography map. River geometry data would require at least 5 themes, namely; stream centerline, banks, flowpath centerline, crosssectional cut lines, and Manning roughness coefficient value. The first 3 themes were in order to the outer direction, both to the right and to the left of the main river channel. For crosssectional cut lines, one condition must be fulfilled; i.e., the data must only cross stream centerline, banks, and flowpath centerline one time, both for the right and the left parts of main river channel.

Probability analysis for steady flow In addition to river geometry, data on the occurrence probabilities for both historical and scenario discharges would also be required, and these were calculated by using continuous probability distribution approach. The initial stage of this approach was to build an empirical distribution model for historical discharge and select the best distribution model in line with Anderson-Darling test. Based on the selected distribution model, the probability distribution parameter value can be determined. Following this, selected distribution model was transformed into cumulative distribution function (cdf), and historical discharge probability was then calculated based on the inverse cdf, defined as shown in Equation [1].

$$
x=F^{-1}(p \mid a, b)
$$

note:

$x=$ the historical discharge for certain return period

$F^{-1} \quad=$ inverse cdf

$p \quad=$ probability value

$a$ and $b=$ parameter values for selected probability distribution

The determination of scenario discharge probability was initiated by calculating the forest extent of Upper Citarum Watershed, and several subwatersheds, including Dayeuhkolot, Majalaya, Cengkrong, and Cangkuang based on digital land use map in 1989, 1993, 2000, 2005, and 2010. Percentage of forest extent was calculated based on the Equation [2].

$$
F_{l, y}=\left(\frac{m_{l, y}}{A_{l}}\right) \times 100 \%
$$

note:

$F_{1, \mathrm{y}}=$ percentage of forest cover at the $l^{\text {th }}$ subwatershed and in year $y$

$m_{l, y}=$ forest extent at the $l^{\text {th }}$ subwatershed and in year $y$, while $\mathrm{A}_{l}$ is $l^{\text {th }}$ subwatershed area

$l=$ a subwatershed with an outlet in Nanjung, Dayeuhkolot, Majalaya, Cengkrong, or Cangkuang

$y=$ year $(y=1989,1993,2000,2005$, and 2010)

The next stage is to estimate empirical distribution parameter value for 5 discharge data periods related to percentage of forest cover (Equation [3]).

$\operatorname{Parm}(a, b)_{l}=\left\{\left(a_{1}, b_{1}\right)_{l} ;\left(a_{2}, b_{2}\right)_{l} ; \ldots ;\left(a_{5}, b_{5}\right)_{l}\right\}$

note:

Parm $(a, b)_{l}$ is parameter $a$ and $b$ for certain probability 
distribution at the- $l^{\text {th }}$ subwatershed (the same notation as Equation [2]), while $\left(a_{1}, b_{1}\right)$ to $\left(a_{5}, b_{5}\right)$ are parameters of $a$ and $b$ for discharge data periods in 1989-1992, 1993-1999, 2000-2004, 2005-2009, and 2010-2012, respectively.

There was a correlation arrangement between the parameter value of empirical distribution (result of Equation [3]) and forest cover percentage (result of Equation [2]), and this was performed for each subwatershed. The relationship between the empirical distribution parameter and forest cover percentage could be defined as shown in Equation [4].

$$
P(i, l)=n_{o}+n_{l} F(l)
$$

note:

$P(I, l)=$ the parameter value at the $i^{\text {th }}$ probability distribution ( $i=a$ parameter or $b$ parameter $)$ and at the $l^{\text {th }}$ subwatershed (same notation as Equation [2]);

$n_{o}$ and $n_{l}=$ regression constant, and $F(l)$ is forest cover percentage at the $l^{\text {th }}$ subwatershed. Based on literature study, it was found that this approach has not been used by other researchers.

Furthermore, based on Equation [4], 3 scenarios of forest cover change were developed, i.e.:

1 First scenario, percentage of forest extent was about $35 \%$ from the total Upper Citarum Watershed area.

2 Second scenario, percentage of forest extent was assumed to experience a decrease so that forest cover remained about $30 \%$.

3 Third scenario, percentage of forest extent at Upper Citarum watershed was only about $25 \%$.

If it were assumed that this empirical distribution model was permanent and probability distribution parameter's assumption followed the result of forest cover change scenario, then $1^{\text {st }}$ until $3^{\text {rd }}$ scenario discharge could be estimated.

Flood scenario Results of HEC-RAS hydraulic model in the forms of flood prone areas for each return period could be obtained after data on river geometry and steady flow (discharge) have been arranged. There were four flood designed in this research:

1 The $1^{\text {st }}$ flood scenario with input components comprising of river geometry and historical discharge data.

2 The $2^{\text {nd }}$ flood scenario with input components comprising of river geometry and the 1 st scenario discharge as a result of forest cover change for 1 st forest scenario.

3 The $3^{\text {rd }}$ flood scenario with input components consisting of river geometry and the 2 nd scenario discharge as a result of forest cover change for 2 nd forest scenario.

4 The $4^{\text {th }}$ flood scenario with input components consisting of river geometry and the 3rd scenario discharge as a result of forest cover change for 3 rd forest scenario.

Based on the model result (i.e., spread of flood under the $1^{\text {st }}$ flood scenario until the 4 th), flood status of the research area could be assessed and determined. However, this could be performed following the tested model result.

Model result testing In this testing, results of the $1^{\text {st }}$ flood scenario were used and highest flood occurrence was selected; that is, flood scenario with a return period of more than 50 years. Horritt and Bates (2002) and Knebl et al. (2005) used the Equation [5] to test their model result:

$\mathrm{F}=\frac{\operatorname{Num}\left(S_{\text {mod }} \cap \mathrm{S}_{\text {obs }}\right)}{\operatorname{Num}\left(S_{\text {mod }} \cup \mathrm{S}_{\text {obs }}\right)} \times 100 \%$

note:

$S_{\text {mod }}$ is the sets of pixels or cells predicted as flooded by the model; $S_{\text {obs }}$ represents the number of pixels or flood cells exist in satellite image; and, Num (.) shows the number of members of pixel collection. $F$ value varies, ranging $0 \%-100 \%$; the higher the percentage of model result, the better and the more feasible is the model. Details of methodology used in this research is depicted in Figure 1.

\section{Results and Discussion}

Geographically, Upper Citarum Watershed lies at longitude $107.38^{\circ} \mathrm{E}$ to $107.95^{\circ} \mathrm{E}$ and at latitude $6.76^{\circ} \mathrm{S}$ to $7.26^{\circ} \mathrm{S}$, with a catchment area of 18,0270 ha. Topography in this region extends from hilly to mountainous areas but flat in the middle to form a basin area (Figure 2). According to BBWS Citarum (2010), this kind of topography is prone to flood inundations and the occurrence increases from year to year.

Upper Citarum River geometry Position, length, and number of cross sections became crucial inputs in water surface profile calculation using HEC-RAS. Cook and Merwade (2009) stated that the addition of cross sections would be followed by an increase of model result detail level. Based on this, the number of cross sections in study area was increased from 44 to 324 using interpolation technique. The width of cross-sections ranged 600-11,700 $\mathrm{m}$ with an average spacing of $200 \mathrm{~m}$. The result of river geometry analysis showed that cross section formed in Dayeuhkolot areas to Majalaya represented a big "U" letter; as a result, this region was topographically more prone to flood inundations than other areas such as Nanjung, Cangkuang, and Cengkrong that represented a "V" letter.

Steady flow frequency analysis In this research, the volume of steady flow (discharge) was studied according to the historical and scenario conditions. Frequency of occurrence of the 2 discharges was analyzed using probability distribution approach, i.e. Gamma distribution for Nanjung and Dayehkolot, Weibull for Cengkrong, and Log-Normal for Cangkuang. Based on such probability distribution, the volume of both historical discharge and scenario for several return periods could be calculated

Furthermore, historical discharge and scenario data related to forest cover change have also been compared and the results were shown in Figure 3. As seen in Figure 3a, historical discharge in Nanjung was estimated to reach about $54.8,167.5$, and $277.0 \mathrm{~m}^{3} \mathrm{~s}^{-1}$ in return period of 2,10 , and 50 years, respectively. Nevertheless, when forest in upstream of Nanjung remained only $25 \%$ (the $3^{\text {rd }}$ forest scenario), the discharge values were $74.6,237.5$, and $398.2 \mathrm{~m}^{3} \mathrm{~s}^{-1}$ or increased by approximately $36 \%, 42 \%$, and $44 \%$ in return period of 2,10 , and 50 years, respectively. This condition was similar to what occurred in Cengkrong (Figure 3c); meaning that forest cover shrinkage in this area would 


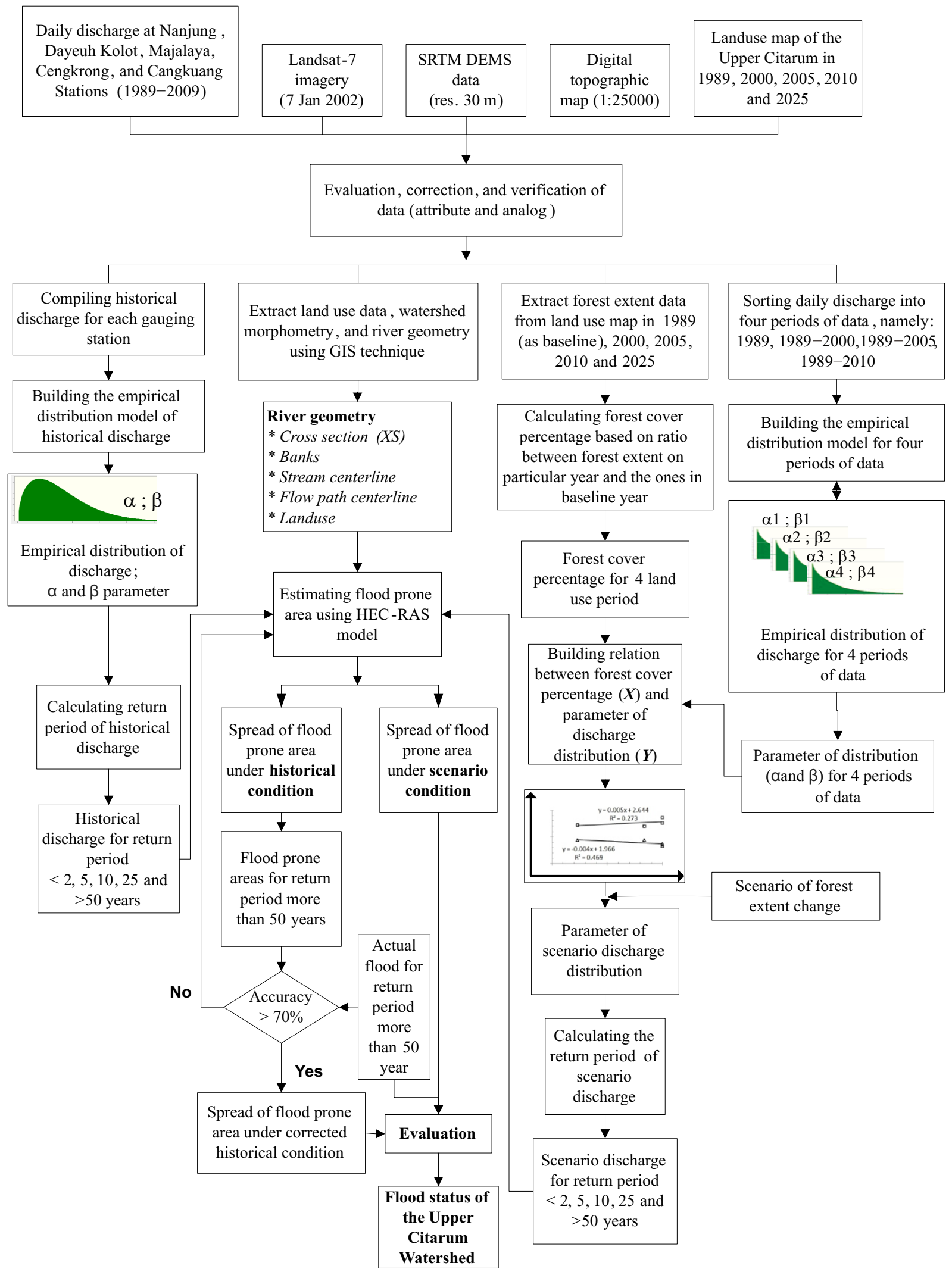

Figure 1 Flow the estimation and mapping of flood inundation according to historical and scenario discharges using 1D HECRAS model. 


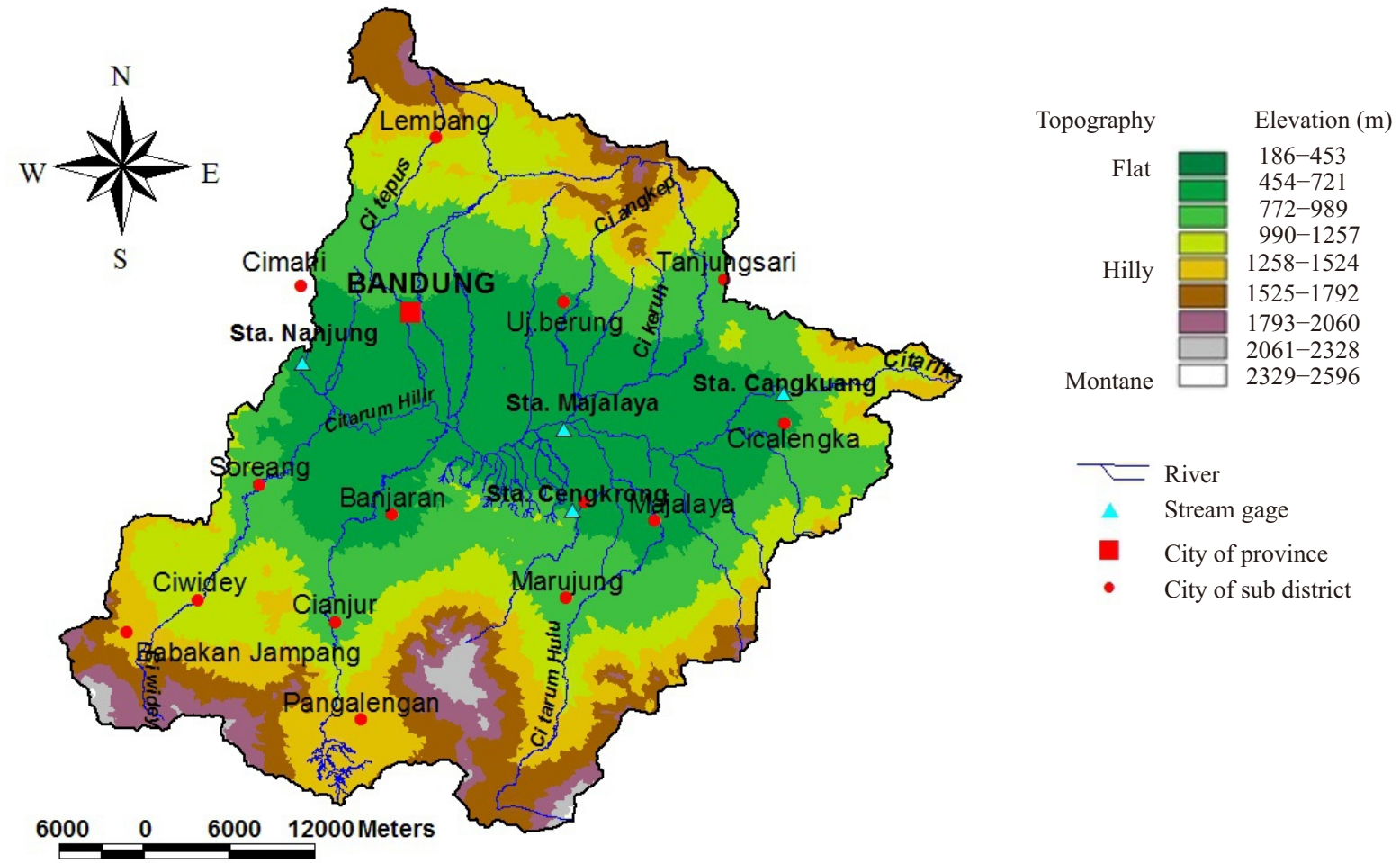

Figure 2 Topographic form and elevation status of the Upper Citarum Watershed.
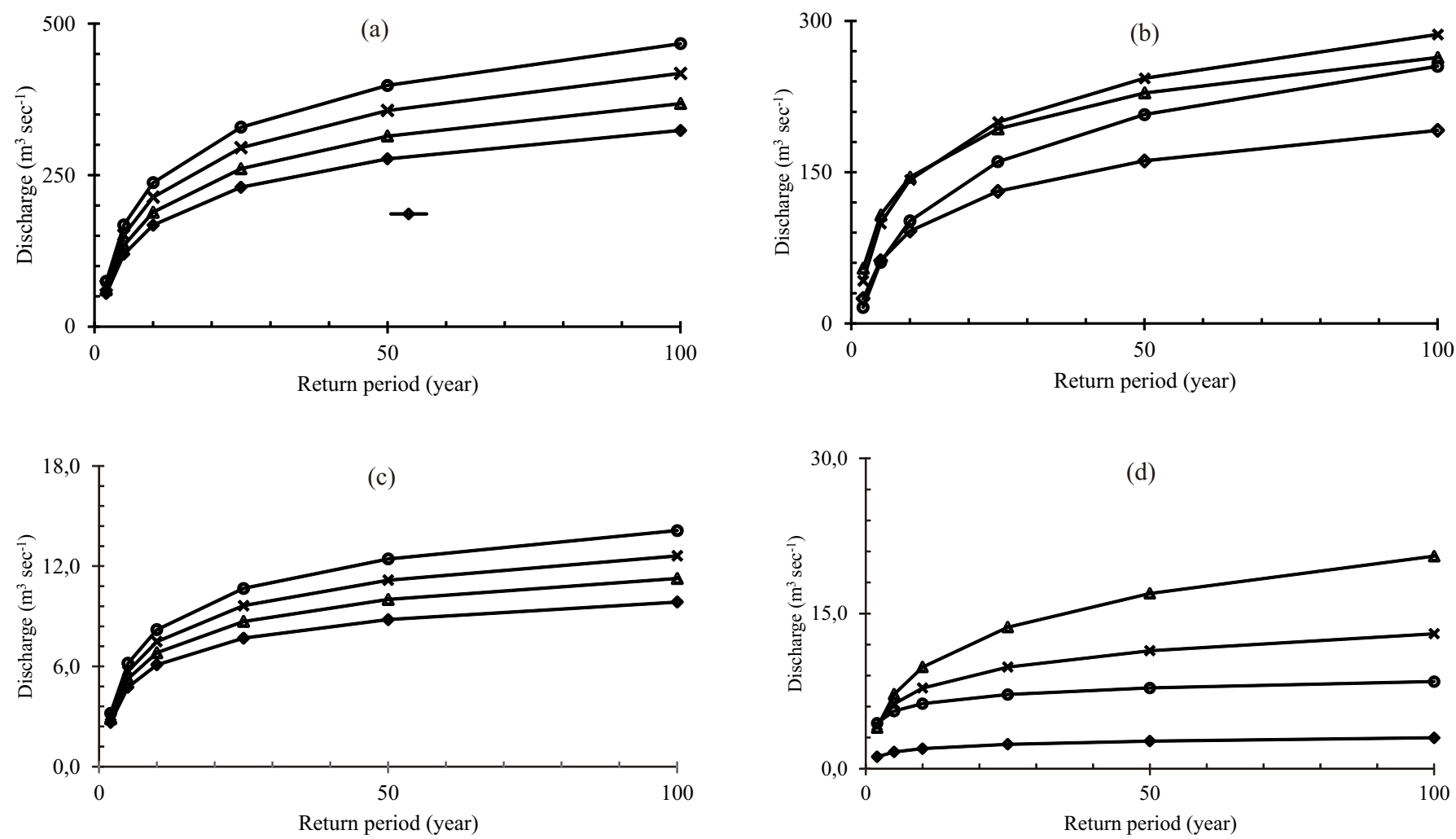

Figure 3 Comparison between the historical discharge and scenario at four gauging station, i.e. Nanjung (a), Dayeuhkolot (b), Cengkrong (c), and Cangkuang (d). The $1^{\text {st }}-3^{\text {rd }}$ scenario discharge represent forest cover percentage about $25-35 \%$. Historical discharge $(-\infty), 1^{\text {st }}$ scenario discharge $(-\infty), 2^{\text {nd }}$ scenario discharge $(\rightarrow), 3^{\text {st }}$ scenario discharge $(-\infty)$. 
increase the river discharge level for each certain return period.

Figure $3 b$ and Figure $3 d$ showed different results when these were compared with Figure $3 \mathrm{a}$ and Figure $3 \mathrm{c}$. According to Figure 3b (Dayeuhkolot Station), the $3^{\text {rd }}$ scenario discharge would decreased sharply about $35 \%$ from historical discharge in 2-year return period, but in return period of 10 and 50 year, the scenario discharge would increased to about $11 \%$ and $29 \%$ from the historical discharge. At Cangkuang Station (Figure 3d), percentage of the $3^{\text {rd }}$ scenario discharge changed against historical discharge would increase rapidly more than $150 \%$ in return period of 2, 10, and 50 years. This findings were in line with the studies conducted by Wangcheng (1983), Bruijnzeel (1990), Costa et al. (2003), and Peña-Arancibia et al. (2012). They revealed that the effect of forest cover shrinkage on surface runoff, peak discharge, and flood volume would emerged in small scale catchment $\left(<1 \mathrm{~km}^{2}\right)$, but for larger catchment $\left(>100 \mathrm{~km}^{2}\right)$ the impact would increase or decrease. The Upper Citarum Watershed could be grouped as large-scale catchment, and the total catchment area was more than $1800 \mathrm{~km}^{2}$. In this large-scale catchment, forest cover reduction has caused a change of river discharge level in all hydrometry stations (i.e. Nanjung, Dayeuhkolot, Cengkrong, and Cangkuang). Generally, an increase of river discharge would occured in return period of more than 2 year, while in 2-year return period, this event might be similar or the opposite.

Flood scenario at the Upper Citarum Watershed In this case, distribution of flood prone area according to scenario discharge as a result of forest cover change, could be simulated using HEC-RAS model, and the result could be shown in the following sub-part.

Model result accuracy Results of flood simulation using
HEC-RAS model indicated that the spread of flood areas in the Upper Citarum Watershed extent from Cilampeni (village in eastern Nanjung Station) to some villages in Rancaekek Subdistrict. The width of flood inundation was estimated to stretch from north to south and its spread depended on the topographic form of the region. The estimated flood extents which was produced by HEC RAS model fit the result of the Landsat-7 image recorded on Januari 7, 2002, during the time when Upper Citarum underwent huge flood (return period of more than 50 years). Resemblance level between the resulted and observed (Landsat imagery) model was approximately $74 \%$ (Figure 4c), meaning that the model is able to predict flood extent and spread with about $74 \%$ accuracy; consequently, this model is feasible to be used in further analysis.

Flood scenario Figure 5 showed the spread of flood areas for return period of 2 and 50 years under the $1^{\text {st }}$ flood scenario and $4^{\text {th }}$, respectively. Figure 5 a showed the flood prone areas under the $1^{\text {st }}$ flood scenario. As shown in this figure, flood coverage with a return period of 2 year has reached more than $42 \mathrm{~km}^{2}$ and this caused floods in 60 villages (Figure 5a1), where the largest flood coverage occurred in Sumbersari Village of Ciparay District (nearly $4.75 \mathrm{~km}^{2}$ ). In return period of 50 years (Figure 5a2), flood coverage was more than 100 $\mathrm{km}^{2}$ and it would inundate approximately 98 villages; in this flood period, flood coverage in Sumbersari Village of Ciparay District has reached more than $7 \mathrm{~km}^{2}$. Flood coverage and spread for each return period (2 years and 50 years) were predicted to change when there is forest cover reduction in the upper part, the detail of which is shown in Figure $5 b$.

Figure $5 \mathrm{~b}$ revealed that the $4^{\text {th }}$ flood scenario, which was built from the $3^{\text {rd }}$ scenario discharge and forest cover in this scenario was about $25 \%$ of Upper Citarum Watershed area. In return period of 2 and 50 year, the flood coverage and
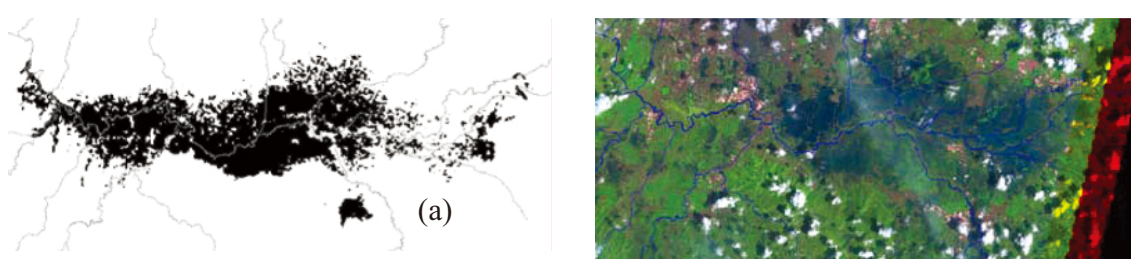

(b)
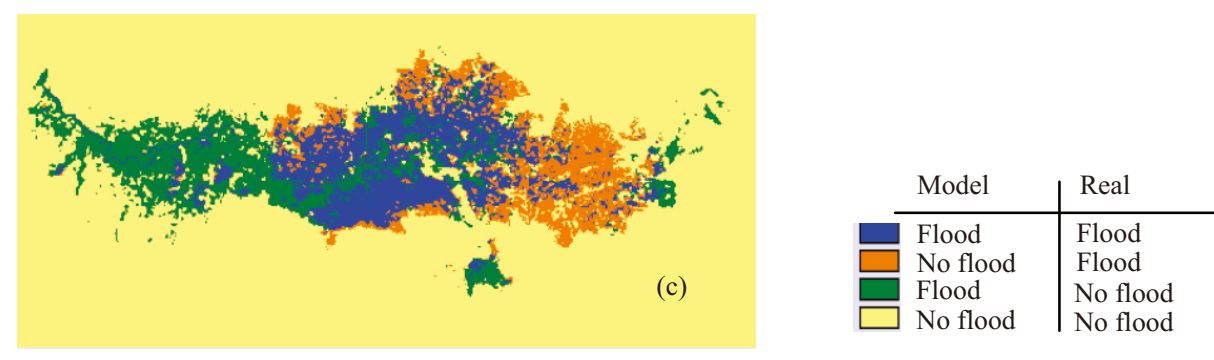

Figure 4 (a) Showed spread of flood as results of HEC-RAS model and (b) was actual/real flood which was extracted from Landsat-7 imagery (acquisition date: 07-01-2002), while (c) constituted result of overlay between (a) and (b) for return period of 50 years. 


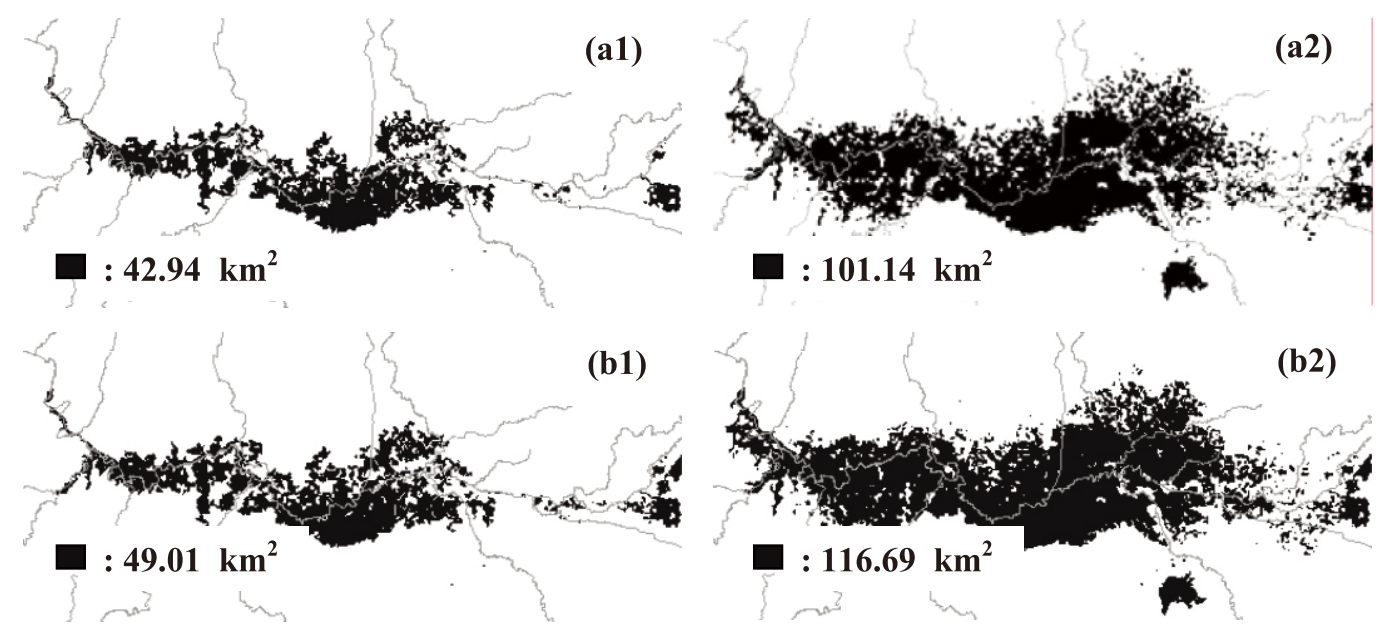

Figure 5 Flood estimation used HEC-RAS model for return period of 2 year (a1; b1) and 50 year (a2; b2). Figure (a) showed spread of flood areas under the $1^{\text {st }}$ flood scenario, while (b) showed result of the $4^{\text {th }}$ flood scenario.

Table 1 Flood extents according to the $1^{\text {st }}$ flood scenario until $4^{\text {th }}$ for return period $2,5,10,25,50$, and 100 years on the Upper Citarum Watershed

\begin{tabular}{ccccc}
\hline \multirow{2}{*}{ Return period (year) } & \multicolumn{5}{c}{ Flood $\operatorname{area}^{2}(\mathrm{~km})$} \\
\cline { 2 - 5 } & $1^{\text {st }}$ scenario & $2^{\text {nd }}$ scenario & $3^{\text {rd }}$ scenario & $4^{\text {th }}$ scenario \\
\hline 2 & 42.94 & 50.21 & 49.94 & 49.01 \\
5 & 62.87 & 68.87 & 70.05 & 70.03 \\
10 & 70.36 & 79.57 & 83.51 & 84.64 \\
25 & 86.47 & 97.19 & 100.15 & 101.16 \\
50 & 101.14 & 110.35 & 114.63 & 116.69 \\
100 & 107.71 & 117.45 & 122.29 & 125.52 \\
\hline
\end{tabular}

spread as a result of $4^{\text {th }}$ flood scenario (Figure 5b) was larger than the result of the 1 st flood scenario (Figure 5a). These results showed that the impact of forest cover shrinkage would be clearly seen in flood with a long term return period. The detail proof of this matter could be seen in Table 1.

Table 1 showed flood extent changes according to the 1 st flood scenario until the $4^{\text {th }}$ and in the return period of 2 until 100 years. As could be seen in the table, in 2-year return period, flood extents under the first flood scenario was about $42.9 \mathrm{~km}^{2}$. However, in the $2^{\text {nd }}$ flood scenario it increased sharply $\left(50.2 \mathrm{~km}^{2}\right)$ but in the $3^{\text {rd }}$ flood scenario and $4^{\text {th }}$ it decreased slightly. In contrast, in return period of more than 2 year, flood extents would increased sharply in all flood scenario. In this research, flood scenario was built based on forest cover reduction. Based on Table 1 and focus of the research, it can be concluded that flood extent changes was very much affected by forest cover changes.

\section{Conclusion}

The modeled flood extent has an accuracy level of about $74 \%$. Based on the model results, forest cover shrinkage caused the increased of discharge value, as clearly identified in Nanjung, Dayeuhkolot, Cengkrong, and Cangkuang hydrometric stations. Moreover, flood coverage and spread in Upper Citarum region were largely affected by not only natural but also anthropogenic factors. Forest cover change was only one of the anthropogenic factors that might influence the rise or fall of discharge value which further caused the change in flood coverage and spread in Upper Citarum Watershed. Effect of forest cover reduction on river discharge level and spread of flood areas was unclear in the return period of 2 years but this was opposite for return period of more than 2 years.

\section{Suggestion}

Results of this research revealed that forest cover change was not a determining factor in discharge increase and flood coverage. This indicated that there were, indeed, other factors that played an essential role; therefore, it was suggested to revise and extent forest cover types into vegetation cover types for further research in order to sharpen the research results.

\section{Acknowledgement}

This article is part of a doctoral research conducted by the main author, who is currently pursuing a post graduate study 
in the Natural Resources and Environmental Management Programme (PSL) of Bogor Agricultural University, Bogor. The author would like to express his gratitude to Prof. Dr. Ir. Hidayat Pawitan, M.Sc. who has improved the author's concept and understanding on hydrology so that this article has finally been completed. The author would also like to thank Dr. Budi Kartiwa, CESA for all of his assistances including proving discharge data measured in several hydrometric stations in Upper Citarum Watershed. We would like to thank the three anonymous reviewers whose comments led to significant improvement of the earlier version of this manuscript.

\section{References}

Andre'assian V. 2004. Waters and forests: from historical controversy to scientific debate. Journal of Hydrology 29:1-27. http://dx.doi.org/10.1016/j.jhydrol.2003. 12.015 .

Apip, Takara K, Yamashiki Y, Ibrahim AB. 2010. Assessment of Spatially-Distributed Sediment Budget and Potential Shallow Landslide Area for Investment Prioritization in Sediment Control of Ungauged Catchment: A Case Study on the upper Citarum River, Indonesia. Annuals of Disaster Prevention Research Institute, Kyoto University.

[BBWS Citarum] Balai Besar Wilayah Sungai Citarum. 2010. Achieving better Citarum River through integrated water resources management. http://citarum.org/upload/ upload/citarum factsheet Mencapai Sungai Citarum yang Lebih Baik 16 June 10.pdf[18 March 2012].

Boer R, Dasanto BD, Perdinan, Martinus D. 2012. Hydrologic balance of Citarum Watershed under current and Future Climate. In: Climate Change and the Sustainable Use of Water Resources, Climate Change Management. Filho WL, editor. Berlin: Springer Berlin Heidelberg.

Boer R, Perdinan, Delon, Faqih A. 2003. Assessing the impact of land use change and climate change on river flow at citarum Upper Catchments. In: An Integrated Assessment of Climate Change Impacts, Adaptation and Vulnerability in Watershed Areas and Communities in Southeast Asia (Working Paper of AIACC-AS21). Washington: The International START Secretariat.

Bosch JM, Hewlett JD. 1982. A review of catchment experiments to determine the effect of vegetation changes on water yield and evapotranspiration. Journal of Hydrology 55:3-23. http://dx.doi.org/10.1016/00221694(82)90117-2.

Brown AE, Zhang L, McMahon TA, Western AW, Vertessy RA. 2005. A review of paired catchment studies for determining changes in water yield resulting from alterations in vegetation. Journal of Hydrology 310:28-61. http://dx.doi.org/10.1016/j.jhydrol. 2004.12.010.
Bruijnzeel LA. 1990. Hydrology of Moist Tropical Forests and the Effects of Conversion: A State of Knowledge Review. Paris: UNESCO International Hydrological Programme.

Bruijnzeel LA. 2004. Hydrological functions of tropical forests: not seeing the soils for the trees? Agriculture Ecosystems and Environment. 104:185-228. http://dx.doi.org/10.1016/j.agee.2004.01.015.

Cook A, Merwade V. 2009. Effect of topographic data, geometric configuration and modeling approach on flood inundation mapping. Journal of Hydrology 377:131-142. http://dx.doi.org/10.1016/j.jhydrol. 2009.08.015.

Cook AC. 2008. Comparison of one-dimensional HEC-RAS with two-dimensional FESWMS model in flood inundation mapping [thesis]. Indiana: Purdue University.

Costa MH, Bottab A, Cardille JA. 2003. Effects of largescale changes in land cover on the discharge of the Tocantins River, Southeastern Amazonia. Journal of Hydrology 283:206-217. http://dx.doi.org/10.1016/ S0022-1694(03)00267-1.

Dingman SL. 1994. Physical Hydrology. New York: MacMillan Publ.Co.

Du J et al. 2012. Assessing the effects of urbanization on annual runoff and flood events using an integrated hydrological modeling system for Qinhuai River basin, China. Journal of Hydrology 464-465:127-139. http://dx.doi.org/10. 1016/j.jhydrol.2012.06.057.

Ellison D, Futter MN, Bishop K. 2012. On the forest coverwater yield debate: from demand to supply side thinking. Global Change Biology 18:806-820. http://dx.doi.org/10.1111/j.1365-2486.2011.02589.x.

Fares YR, Yudianto D. 2004. Hydrological modeling of the Upper Citarum Catchment, West Java. Journal of Environmental Hydrology 12:1-13.

Farley KA, Jobba'gy EG, Jackson RB. 2005. Effects of afforestation on water yield: a global synthesis with implications for policy. Global Change Biology 11:1565-1576. http://dx.doi.org/10.1111/j.13652486.2005.01011.x.

Hendrayanto, Soedomo S. 2013. Hydrological services of forests and their compensation initiatives. Jurnal Manajemen Hutan Tropika 19(1):79-84. http://dx.doi. org/10.7226/jtfm.19.1.79.

Hibbert AR. 1967. Forest treatment effects on water yield. http://coweeta.uga.edu/publications/842.pdf [6 May 2014]

Horritt MS, Bates PD. 2002. Evaluation of 1D and 2D numerical models for predicting river flood inundation. Journal of Hydrology 268:87-99. http://dx.doi.org/10. 


$$
\text { 1016/S0022-1694(02)00121-X. }
$$

Hunter NM, Bates PD, Horritt MS, Wilson MD. 2007. Simple spatially-distributed models for predicting flood inundation: a review. Geomorphology 90(3-4):208-225. http://dx.doi.org/10.1016/j. geomorph.2006.10.021.

Knebl MR, Yang ZL, Hutchison K, Maidment DR. 2005. Regional scale flood modeling using NEXRAD rainfall, GIS, and HEC-HMS/RAS: a case study for the San Antonio River Basin Summer 2002 storm event. Journal of Environmental Management 75:325-336. http://dx.doi.org/10.1016/j.jenvman.2004.11.024.

Lima WP, Laprovitera R, Ferraz SFB, Rodrigues CB, Silva MM. 2012. Forest plantations and water consumption: a strategy for hydrosolidarity. International Journal of Forestry Research 2012:1-8. http://dx.doi.org/ $10.1155 / 2012 / 908465$.

Moore RD, Wondzell SM. 2007. Physical hydrology and the effects of forest harvesting in the Pacific Northwest: a review. Journal of the American Water Resources Association (JAWRA) 41(4):763-784. http://dx.doi.org/ 10.1111/j.1752-1688.2005.tb04463.x.

Peña-Arancibia JL et al. 2012. Detecting changes in streamflow after partial woodland clearing in two large catchments in the seasonal tropics. Journal of Hydrology
416-417:60-71.

Sahin V, Hall MJ. 1996. The effects of afforestation and deforestation on water yields. Journal of Hydrology 178:293-309. http://dx.doi.org/10.1016/0022-1694 (95)02825-0.

USACE. 2002. HEC-GeoRAS, An Extension for Support of HEC-RAS using ArcView GIS. Davis CA: U.S. Army Corps of Engineers.

USACE. 2010. HEC-RAS (Version 4.1), River Analysis System, Hydraulic Reference Manual. Davis CA: U.S. Army Corps of Engineers.

Wang Y, Yang X. 2013. Land use/cover change effects on floods with different return periods: a case study of Beijing, China. Frontiers of Environmental Science \& Engineering 7(5):769-776. http://dx.doi.org/10.1007/ s11783-013-0542-z.

Wilk J. 2002. Hydrological impacts of forest conversion to agriculture and local perceptions in a large river basin in Northeast Thailand. In: Proceedings of the $12^{\text {th }}$ ISCO Conference; Beijing, May 26-31, 2002.

Zhou $\mathrm{G}$ et al. 2010. Forest recovery and river discharge at the regional scale of Guangdong Province, China. Water Resource Research 46:1-10. http://dx.doi.org/10. 1029/2009WR008829. 